\title{
Constitutional Law and the Alberta Energy Regulator
}

\author{
Kirk N. Lambrecht Q.C.*
}

\section{Introduction}

This essay reviews general principles regarding a tribunal's ability to consider constitutional law, and then makes observations about the Alberta Energy Regulator (the Regulator or AER) and its capacity to consider constitutional law. The question ultimately explored is the Regulator's capacity to both respect and contribute to the fulfilment of the constitutional norms and obligations of the province that created it.

The Regulator is the successor to the Energy Resources Conservation Board (ERCB), and is an important component of the Government of Alberta's Regulatory Enhancement Project. ${ }^{1}$ This project resulted in legislation presenting a profound change in the energy sector in Alberta, one described as "significant and sweeping regulatory reform that, arguably, is unprecedented in Alberta's energy development history." 2 The change occurs at a time when energy development in Alberta is a matter of both provincial and national priority, and when the law respecting the ability of tribunals to consider and apply constitutional law is evolving. It is appropriate that, at this early time in its history, the Regulator's competence to consider and apply constitutional law be considered.

This essay discusses the function of the Regulator in relation to the following elements of constitutional law:

- the division of powers inherent in ss $91 / 92$ of the Constitution Act, 1867;
- the Charter of Rights and Freedoms, which is Part I of the Constitution Act, 1982; and

- First Nations Treaty and asserted Métis rights, constitutionally protected by

- the honour of the Crown (for both First Nations and Métis); and also by

- the Natural Resources Transfer Agreement with Alberta, which is schedule 2 of the Constitution Act, 1930 (for First Nations), and/or

- s 35 of the Constitution Act, 1982 (for First Nations/Métis, respectively).

The observations made here are that the Regulator is a tribunal with inferred power to consider questions of law, including questions of constitutional law arising in the course of its functions. This inferred power is explicitly confirmed by the fact that the Regulator is designated by the Lieutenant Governor ${ }^{3}$ as having the authority to consider all questions of constitutional law as defined in the Administrative Procedures and Jurisdiction Act ("APJA"). ${ }^{4}$

The Regulator is also obligated to consider public interest under the legislation it administers. This introduces the potential, still largely unexplored in Alberta's judicial consideration, that the constitutional dimensions of issues that arise in the course of the Regulator's work may give rise to "a special public interest." ${ }^{5}$ This interest can inform the mandates and purposes of 
the energy, public lands, lands, environmental assessment and water legislation which the Regulator applies.

From this broad capacity to consider constitutional law, the Alberta legislature has withheld from the Regulator any jurisdiction to assess the adequacy of Aboriginal consultation by the Crown. ${ }^{6}$

This otherwise broad capacity is also further limited, perhaps erroneously, because the Regulator has given an interpretation to the APJA that narrowly limits its capacity to consider constitutional issues.

\section{First Principles: Tribunals and Constitutional Law}

Canada's executive branches of government consider and apply constitutional law as they exercise their respective powers. Governments in Canada also have power to create tribunals and to confer upon those tribunals the ability to exercise powers formerly exercised by the executive branches of government. The overall context is described by Chief Justice McLachlin as

...the practice of delegating of executive functions to administrative tribunals. Work formerly done by civil servants under the direction of a minister, answerable to Parliament, is assigned to independent bodies set up for this purpose. This development is also justified on the ground that it is required for effective governance in the complex modern state. The result is that modern governments, federal and provincial, discharge the majority of their functions through a plethora of independent administrative tribunals like labour tribunals, pension boards, licencing boards, immigration appeal boards, and human rights tribunals. These boards and tribunals are not answerable to Parliament, as are the civil servants they replace. They are answerable only to courts, which may be asked to rule on whether particular rulings are within the statutory powers of a board or tribunal and conform to the principles of natural justice. ${ }^{7}$

This, the Chief Justice observes, is the reality of the regulatory state.
Tribunals are limited to the powers conferred upon them by enabling legislation, with one exception. ${ }^{8}$ These powers are given the large and liberal interpretation necessary to attain the tribunal's objectives.

This exception is often forgotten but it should never be overlooked. In addition to power conferred by legislation, every tribunal also has, "by implication," all powers that are reasonably necessary to the effective and efficient performance of tribunal functions and mandates. ${ }^{9}$

A tribunal's ability to consider and apply constitutional law in the exercise of its delegated powers can be uncertain. The Supreme Court observes that "[a]dministrative tribunals vary widely in virtually every respect - experience, expertise, structure, function, resources and mandate. ${ }^{10}$ Their diverse functions and powers make it challenging for them to evolve and apply legal doctrine in the relationship between tribunals and constitutional law.

Tribunals cannot, however, simply ignore constitutional law. Just as an action by the executive branch of government must be consistent with constitutional law, so too must the actions of tribunals created by government. This leads to inherent limitations on power to create tribunals. More importantly, governments are not able to avoid constitutional law associated with the exercise of those powers by way of delegation to tribunals. ${ }^{11}$

Tribunals themselves should strive to comply with constitutional law as their competence may allow. This may involve considering the constitutional validity of their enabling legislation or their own actions pursuant to that enabling legislation. For reasons of good governance, the initial effort to achieve constitutional compliance can be undertaken by tribunals before their actions or decisions are reviewed by the courts. Ultimately, the judiciary must review "actions and decisions of administrative bodies for compliance with the constitutional capacities of government." ${ }^{2}$ This task would be facilitated if tribunals recognize that a 'constitution-free' zone prior to judicial oversight should not exist. 
The Supreme Court's goal has been to shape administrative law to facilitate a general culture of respect ${ }^{13}$ pertaining to constitutional law. This general respect flows from the premise that "tribunals operate within a legal system governed by ... constitutional rights and norms...." ${ }^{14}$

This idea elicits two distinct questions. First, has a tribunal been given power under its enabling legislation to determine a question of constitutional law? Second, can a tribunal grant a remedy, either under its enabling legislation or as a constitutional remedy of some kind?

The answer to the second consideration remedy - may vary according to whether the constitutional question concerns:

- the division of powers (where the competence of the legislator to legislate, and of the tribunal to act, is engaged);

- Charter rights, for which s 24(1) may augment remedial powers of the tribunal; or

- s 35 rights, for which the law (including the law of remedies) is still evolving. ${ }^{15}$

Notably, when considering jurisdiction in constitutional questions or possible remedies, tribunal decisions on matters of constitutional law will not constitute legally binding precedent or create common law. ${ }^{16}$

$R v$ Conway summarizes the present evolution of the law pertaining to jurisdiction over questions of constitutional law. ${ }^{17}$ In this approach, contextual factors reveal whether a tribunal has the capacity to determine questions of law. The power to do so can flow from an explicit power or, alternatively, from a power that is inferred. Regardless, if this power is not subsequently withdrawn or transferred in some way from the tribunal then it may determine constitutional law issues arising from powers conferred upon it. $^{18}$

Conway involves the Charter, but can be seen as part of the Court's attempt at the presentation of a richer conception of administrative law which considers the capacity of tribunals to apply constitutional law generally. For example, the Supreme Court states that "there is no principled basis for distinguishing s 35 rights from other constitutional questions" and that section 35 is not, any more than the Charter or the division of powers, "some holy grail which only judicial initiates of the superior courts may touch." 19 Good governance would suggest that, within the principals outlined above, all tribunals must at least recognize the constitutional norms of the legal system they are a part of; and those tribunals with power to determine questions of law may determine constitutional matters which arise within the statutory functions they discharge.

\section{The Alberta Energy Regulator}

\section{Bill 2}

On October 24, 2012, Bill 2, the Responsible Energy Development Act (REDA), was introduced in the Alberta Legislature. The Bill received Royal Assent on December 10, 2012, and has been proclaimed in force in stages. ${ }^{20}$ Upon the initial proclamation of Bill 2's key provisions, the predecessor tribunal, the ERCB, was dissolved. The enabling legislation of the ERCB, the Energy Resources Conservation Act, was repealed. The Bill's transitional provisions stipulated that the Lieutenant Governor in Council could determine, by regulation, if the REDA could apply to proceedings in progress at the time of the particular proclamation in force. ${ }^{21}$ Transitional regulations were promulgated in June 2012, confirming that the new legislative regime would apply immediately and to all proceedings not yet completed. ${ }^{22}$ All of this received commentary from private law firms and academia. ${ }^{23}$ The commentary suggested that an appreciation of the true impact of the creation of the Regulator would have to wait until REDA was fully in force. This transition occurred on March 31, 2014. ${ }^{24}$

Full implantation of REDA coincided with a particularly critical report on Crown consultation in Alberta. ${ }^{25}$ Material to this paper is the ability of the Regulator to consider project impacts on constitutionally protected Treaty rights. Academic commentary notes that the Regulator had made decisions about project 
impacts on "traditional uses" which are defined in the provincial consultation policy as "customs and practices on the land that are not existing section 35 Treaty rights but are nevertheless important to First Nations." 26 This paper observes (i) that the Regulator's reluctance to engage in a consideration of project impacts on constitutionally protected Treaty rights arises from an unduly narrow reading of the Administrative Procedures and Jurisdiction Act and (ii) is impossible to reconcile with the direction given to the Regulator by Ministerial Order 141/2013, issued by the Minister of Energy under section 67 of REDA. The Ministerial Order "recognizes that the AER has a responsibility to consider potential adverse impacts of energy applications on existing rights of aboriginal peoples as recognized and affirmed under Part II of the Constitution Act, 1982 within its statutory authority under REDA." ${ }^{27}$

\section{Before Bill 2: An Integrated Resource Development Process}

Prior to Bill 2, environmental assessment and regulatory review and oversight responsibilities in Alberta's energy sector were distributed among government departments and tribunals created by the Legislature. Key players included Alberta Energy, Alberta Environment and Sustainable Development, and the ERCB (or, for a period of time, the Alberta Energy and Utilities Board that exercised the authority of the ERCB). The overall system was described as integrated because it attempted to harmonize functions and approvals exercised by the executive branch of government with functions and approvals exercised by tribunals.

The result was a single coordinated process of planning, approval and regulatory oversight. The essence of the integrated provincial process was succinctly described by Associate Professor Nickie Vlavianos of the University of Calgary's Faculty of Law as follows, in which she summarizes the entities that played key roles in this (now historical) process:

Under the existing legislative regime for energy development in Alberta, there are several decision-makers (operating under various statutes) involved. With respect to the $80 \%$ of oil and gas resources owned by the province, Alberta Energy starts the ball rolling with the sale of those oil and gas rights under the Mines and Minerals Act, RSA 2000, c M-17 (MMA). Alberta Environment and Sustainable Resource Development (ESRD) then grants surface leases to companies to develop those rights on public lands and regulates reclamation and those lands pursuant to the Public Lands Act, RSA 2000, c P-10 (PLA). The Energy Resources Conservation Board (ERCB) grants the key licences and approvals for all manner of oil and gas wells and facilities as well as regulates most aspects of those facilities (from construction to operations to final abandonment.) Various statutes set out the ERCB's jurisdiction in this regard including the Oil and Gas Conservation Act, RSA 2000, c O-6 (OGCA), the Oil Sands Conservation Act, RSA 2000, c O-7 (OSCA), and the Pipeline Act, RSA 2000, c P-15 (PA). Along with the ERCB, Alberta ESRD grants licences and approvals in regard to air, land and water impacts relating to certain energy facilities pursuant to the Environmental Enhancement and Protection Act, RSA 2000, c E-12 (EPEA) and the Water Act, RSA 2000, c W-3 (WA). It also conducts environmental impact assessments for some energy facilities, as well as regulates reclamation and remediation over private lands in the province under EPEA. ${ }^{28}$

\section{After Bill 2: A Centralized Resource Development Process}

Bill 2's intent was to centralize these responsibilities into one entity, the Alberta Energy Regulator. The general scheme of Bill 2 is to replace an integrated decision-making process with a centralized one. The AER oversees energy development from application to reclamation, subject only in limited cases to Cabinet oversight via authorization by the Lieutenant Governor in Council. ${ }^{29}$ It is also subject to directions issued by the Minister for the purpose of, inter alia, ensuring that the work of the Regulator is consistent with that of the Government. ${ }^{30}$ The AER also has a broad advisory power conferred upon it, and can make recommendations to the Lieutenant Governor in Council. ${ }^{31}$

Although the Regulator is a corporate entity and not an agent of the Crown, it is neverthe- 
less a public agency pursuant to the Alberta Public Agencies Governance Act. ${ }^{32}$ That Act was proclaimed in force on June 12, 2013, only a few days before the AER was created. Section 1 of the Act defines "adjudicative function." The AER is therefore a public agency that exercises adjudicative functions regarding applications for permits, licences, approval, or other benefits, under energy or other specified enactments.

The responsibilities conferred upon the AER have been grouped into two large categories of enabling legislation: energy resource and specified enactments.

- Energy resource enactments are the Gas Resources Preservation Act, the Oil and Gas Conservation Act, the Oil Sands Conservation Act, the Pipeline Act, the Turner Valley Unit Operations Act, regulations under those enactments, and any additional enactment prescribed through regulations promulgated by the Lieutenant Governor in Council.

- Specified enactments are the Environmental Protection and Enhancement Act, the Public Lands Act, the Water Act, the Mines and Minerals Act (s 8), regulations under those enactments, and any other enactment prescribed by regulations. Section 8 of the Mines and Minerals Act governs exploration licences.

The AER has broad powers of inquiry, broad power to impose remedial measures, and broad enforcement and advisory powers. All can be material to the AER's capacity to respond to constitutional concerns. The Legislature does not appear to confer upon the AER the power necessary to do "everything which it may be asked to do" ${ }^{\prime 3}$ by a person with a constitutional concern, but it appears to have conferred power which is broad enough to enable the AER to do some things, indeed many things. It may, in particular, study and consider these concerns, respond by either imposing conditions through its own project approval decisions or by advising or recommending that the Lieutenant Governor in Council consider matters outside of AER jurisdiction prior to authorization.
The broad powers of inquiry include (for purposes of illustration) those presently defined by ss 15 and 34 of the Responsible Energy Development Act and s 3 of the Responsible Energy Development Act General Regulation, ss 10 and 11 of the Oil Sands Conservation Act, and s 4 of the Pipeline Act. These authorize the Regulator to consider "the public interest". The obligation to consider 'the public interest' was a source of environmental assessment authority before specific environmental legislation was created. It is a broad power which is, to some extent, a duplication of authority now conferred by specific environmental assessment legislation i.e. the Environmental Protection and Enhancement Act. Arguably, this authority to consider the public interest could be used by the Regulator, in any given case, to examine cumulative environmental effects of an application, even where specific environmental legislation may not require a cumulative effects environmental assessment. ${ }^{34}$

Broad remedial powers include (for purposes of illustration) those conferred by ss 14,15 , 17 and 20 of the Responsible Energy Development Act, sections 6 and 14 of the Oil Sands Conservation Act, and section 9 of the Pipeline Act. These authorize the Regulator to impose terms and conditions on approvals which it may issue. The AER may, independently, make a disposition of an application, "on any terms and conditions that the Regulator considers appropriate." The AER may, with the prior approval of the Lieutenant Governor in Council, approve an application on any terms and conditions that it considers appropriate. Also, the Lieutenant Governor in Council may, when authorizing an approval, prescribe terms and conditions.

The AER may enforce conditions of approvals through regulatory oversight. Where there has been a failure to comply with a condition of an approval, then the AER may issue any order it feels is just and reasonable under the circumstances. This may extend, with prior approval of the Lieutenant Governor in Council, to an order of cancellation or suspension of an approval.

Finally, with respect to advisory powers, the AER may, on its own initiative, conduct inquiries and prepare studies and reports pertaining 
to any matter relating to energy resources or the injection of substances into underground formations. It may also recommend to the Lieutenant Governor in Council any related measures it considers necessary or advisable.

\section{The AER has Implied Power to Determine Questions of Law, Including Constitutional} Issues

The legal literature discusses and confirms the statutory mandate of the ERCB to consider questions of law, and is not challenged. ${ }^{35}$ The ERCA's provisions, some of which stipulate that authority is mandated by necessary implication, are also found in the REDA. ${ }^{36}$ Moreover, appeals to the Court of Appeal that arise on questions of law or AER jurisdiction 'strongly suggest' 37 that the power to determine questions of law is necessary to the AER's mandate. This essay accepts the view that the Regulator has inferred power to determine questions of law. It necessarily follows that the Regulator has inferred power to determine constitutional issues which arise in the course of its work.

\section{The AER Has Explicit Power to Determine All Questions of Constitutional Law}

Following the Supreme Court decisions in Martin and Paul, the Alberta government introduced Bill 23, the Administrative Procedures Amendment Act, 2005. This amended the Administrative Procedures Act (as it had existed) and led to the APJA. ${ }^{38}$

During debate in the Legislature, the Minister introducing Bill 23 stated that it was "designed to clarify which Alberta tribunals and boards have the jurisdiction to determine which constitutional questions" [emphasis added]. ${ }^{39}$ The Minister then stated that, after an internal review including consultation with the Attorney General of Alberta, the government was of the view that the EUB (which then included, and exercised the powers of, the ERCB) had a clear need and capacity to determine constitutional issues and a demonstrated capacity in handling them. [emphasis added] ${ }^{40}$ The Minister also stated that the intent of Bill 23 was to
.... allow boards, such as the Energy and Utilities Board, to decide constitutional questions when appropriate, but it will allow the very same board to refer issues that it believes may be beyond its capacity to the court for determination. This will provide flexibility so that the board can conclude its statutory business subject to what the court has to say on the constitutional issue. ${ }^{41}$

The APJA has several operative provisions built upon existing jurisdiction to consider constitutional issues.

First, s 10(d) of the APJA defines the term 'questions of constitutional law' as consisting of two types:

10 (d) 'question of constitutional law' means

(i) any challenge, by virtue of the Constitution of Canada or the Alberta Bill of Rights, to the applicability or validity of an enactment of the Parliament of Canada or an enactment of the Legislature of Alberta; or

(ii) a determination of any right under the Constitution of Canada or the Alberta Bill of Rights.

Second, s 11 of the APJA withdrew from all 'decision-makers' the jurisdiction to consider 'questions of constitutional law' as defined.

11) Notwithstanding any other enactment, a decision maker has no jurisdiction to determine a question of constitutional law unless a regulation made under section 16 has conferred jurisdiction on that decision maker to do so.

Third, ss 11 and 16 of the APJA authorize the Lieutenant Governor in Council to make regulations conferring upon designated decision makers the jurisdiction to consider questions of constitutional law as defined. At all material times, both the ERCB and the Regulator were designated by the Lieutenant Governor as having the authority to consider all questions of constitutional law as defined. ${ }^{42}$

Finally, the legislation imposed in s 12 et seq of the APJA, including the Regulations, a 
notice procedure for questions of constitutional law as defined. Where notice of such a question is placed before a designated decision maker, $\mathrm{s}$ 13(1) of the APJA allows that decision maker to determine whether the Court of Queen's Bench of Alberta is a more appropriate forum to decide the question.

If a referral to the court is made, then the Regulator must suspend the proceedings, in whole or part, pending judicial direction or determination. ${ }^{43}$ The obligation to suspend proceedings pending review by the Court is a provision in the legislation that may operate to discourage referrals to the Court.

\section{Narrow Interpretation of the APJA May Erroneously Narrow the Competence of the Regulator to Consider Constitutional Issues Including Project Impacts on Constitutionally Protected Rights}

This legislative initiative can be examined in one of two ways.

First, designated tribunals like the Regulator may have jurisdiction to consider constitutional issues by reason of their jurisdiction to consider questions of law. Removed from this broad jurisdiction is the capacity to consider questions of constitutional law as defined. The jurisdiction removed from all tribunals is subsequently bestowed on the Regulator because it is a designated constitutional decision maker.

In this model, the scope of constitutional issues is broader than the scope of questions of constitutional law, and as such the latter becomes a subset of the former. The tribunal in that case may consider and apply constitutional law in the normal course of its functions, but if the constitutional issue is also a question of constitutional law, then statutory notice must be given.

In this model, the defined term 'questions of constitutional law' does not encompass all constitutional issues. See for example: Mikisew Cree First Nation v Canada, 2004 FCA 66, [2004] 3 FCR 436, at paras 70-81. The model anticipates that constitutional law issues cannot be constrained to the definitions of the phrase 'questions

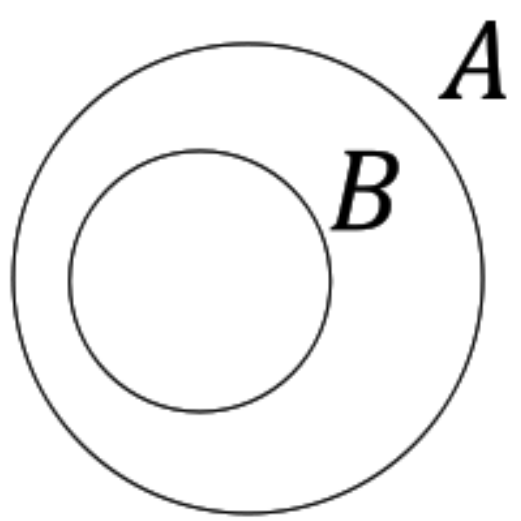

$$
\begin{aligned}
& \mathrm{A}=\begin{array}{l}
\text { jurisdiction to consider constitutional } \\
\text { issues }
\end{array} \\
& \mathrm{B}=\begin{array}{l}
\text { jurisdiction to consider questions of } \\
\text { constitutional law }
\end{array}
\end{aligned}
$$

of constitutional law' in the APJA. The Legislature enacted the Act upon an existing jurisdiction. The AER may consider constitutional issues which are not questions of constitutional law as defined. In those cases a Notice of Question of Constitutional Law is not a necessary precondition to the capacity of the Regulator to consider every constitutional issue which may arise before it, and would not necessarily be required for the Regulator to consider project impacts on constitutionally protected Treaty rights.

A second model is that A and $B$ are coterminous. This model was favoured by the AER in Decision ABAER 2013-014. ${ }^{44}$

This second model illustrates where the Legislature has removed from all tribunals in Alberta the jurisdiction to consider any constitutional issues. It then conferred upon designated tribunals the jurisdiction to consider questions of constitutional law as defined, but provided that a notice in the requisite form is delivered.

The difference between the two models is profound. In the coterminous model, the Regulator would have no jurisdiction to consider constitutional issues in the absence of a notice permitting questions of constitutional law to be considered. Further, its jurisdiction to consider constitutional issues would be limited to matters 


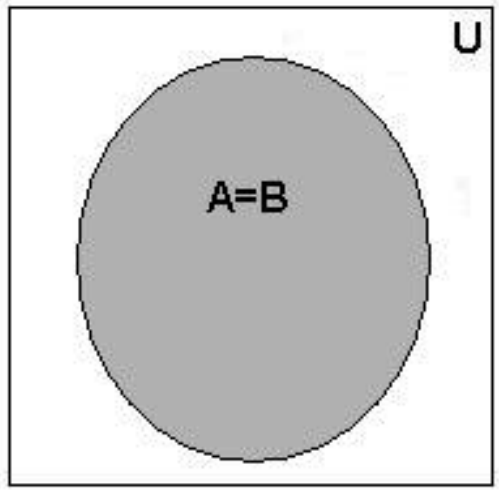

$A=$ jurisdiction to consider constitutional issues

$\mathrm{B}=$ jurisdiction to consider questions of constitutional law

within the definition of questions of constitutional law in s $10(\mathrm{~d})$ of the APJA.

\section{This Potential Error Has Particular Significance}

Statute laws may be unconstitutional because of their incidental effects rather than their dominant purposes. ${ }^{45}$ The Supreme Court states in Paul that "[a] provincially constituted board cannot respect the division of powers under the Constitution Act, 1867 if it is unable to take into account the boundary between provincial and federal powers." ${ }^{6}$ This is particularly the case with the application of provincial statutes, which may be inoperative in certain contexts by virtue of the doctrine of inter-jurisdictional immunity. ${ }^{47}$

The word 'applicability' in s 10(d)(i) of the APJA would seem sufficiently broad to enable the Regulator to determine not only if legislation is valid but also if its own actions pursuant to valid legislation of general application may be constitutionally applicable in a particular context. However, in AER Decision ABAER 2013-014, the Regulator accepted the view of the Attorney General of Alberta, who had argued that s 10(d) (i) was limited to direct challenges to the validity of legislation and did not authorize consider- ation of the constitutional validity of action by the Regulator.

This distinction has broad implications for the Regulator's ability to address constitutional law pertaining to Aboriginal Treaty rights in Alberta. Rights under Treaties 6, 7 and 8 are constitutionally protected not only by ss 35 and 52 of the Constitution Act, 1982, but also by the Natural Resource Transfer Agreement with Alberta, which is Schedule 2 in the Constitution Act, 1930. Authors McNeil and LaForest have analyzed the historical developments that initiated constitutional protection for Aboriginal people. These protections are judicially considered in numerous Supreme Court cases, including: $R$ $v$ Sutherland; ${ }^{48}$ Derrickson $v$ Derrickson ${ }^{49} R v$ Horseman; ${ }^{50} R v$ Badger $;{ }^{51} R v$ Gladstone; ${ }^{52}$ and $R$ $v$ Blais. ${ }^{53}$ Peter Hogg identifies the NRTA as one of the "exceptions to the general rule that provincial laws apply to Indians and lands reserved for Indians." ${ }^{54} \mathrm{He}$ describes the NRTA as "[a] further limitation on provincial competence to make laws applicable to Indians" ${ }^{\prime 5}$ and confirms that, subject to games laws intended to protect the supply of game, "provincial laws cannot affect treaty rights." ${ }^{\prime 6}$ Hogg also states that the NRTA is "a right of the Indians to take game and fish for food" and that "provincial laws cannot deprive Indians of this right." 57

Energy development in Alberta is now predicted to reach such a scale in the coming years that First Nations people may reasonably assert, in any given context, a conflict between Treaty rights, which include the right to fish, hunt, or trap, or to have a supply of game necessary to exercise these rights, and the Regulator's action in approving energy resource activities under the energy or specified enactments. Many legal commentators have identified this as a risk pertaining to woodland caribou specifically. Woodland caribou appear on our Canadian quarter, but may be altogether extirpated from Alberta. ${ }^{58}$ The significance of moose and caribou to Treaty 8 rights to hunt for food is not in dispute, and received judicial recognition in $R v$ Horseman. ${ }^{59}$

If the Regulator's actions are only valid within the scope of constitutional authority enjoyed by the Province, ${ }^{60}$ then it must examine whether 
execution of its mandate under a generally applicable provincial law may trench upon the core of Indianness so as to become inapplicable in a particular context. ${ }^{61}$

The obligation to adhere to constitutional limits applies to tribunals exercising discretion, since they must comply with the constitution when exercising their statutory discretion. ${ }^{62}$ Adjudication by a tribunal in such a case simply takes existing rights into account ${ }^{63}$ and recognizes that a tribunal has the power to apply valid laws of general application "only to those factual situations to which they are constitutionally applicable, or to the extent they do not run afoul of s 35 rights." ${ }^{4}$ This obligation necessarily flows from s 52 of the Constitution Act, 1982, and applies to tribunals endowed with the power to consider questions of law. Consistency with the Constitution is a question of law arising under that provision, and is "the most fundamental question of law one could conceive. [It] will determine whether the enactment is valid law, and thus whether it ought to be interpreted and applied as such or disregarded." ${ }^{65}$

\section{Aboriginal Consultation \& the Assessment of Projects Impacts on Constitutionally Protected Aboriginal Rights}

In 2013, shortly after the Regulator was created, Alberta introduced its Policy on Consultation with First Nations on Land and Natural Resource Management, 2013. ${ }^{66}$ The document states that "Alberta's management and development of provincial Crown lands and natural resources is subject to its legal and constitutional duty to consult First Nations and, where appropriate, accommodate their interests when Crown decisions may adversely impact their continued exercise of constitutionally protected Treaty rights."

In recent years, First Nations and Métis groups have asserted constitutional challenges to oil sands development in their Notices of Constitutional Question filed with the Energy Resources Conservation Board.$^{67}$ In particular, two cases reached the Alberta Court of Appeal by way of leave application, ${ }^{68}$ and one of these reached the Supreme Court by way of a further application for leave to appeal. ${ }^{69}$
A common feature of these Notices was the assertion that the ERCB must assess the adequacy of Crown consultation before issuing project approvals under its enabling legislation. The focus of these challenges was on the competence of the ERCB to assess consultation and accommodation by the Crown itself, and not on the competence of the ERCB to assess consultation obligations delegated to a proponent of the Crown. The constitutional issues raised were never determined on their merits.

Alberta's REDA now states in $\mathrm{s} 21$ that the AER "has no jurisdiction with respect to assessing the adequacy of Crown consultation associated with the rights of Aboriginal peoples as recognized and affirmed under Part II of the Constitution Act, 1982."

The law of Aboriginal consultation in Canada as recognized by the Supreme Court of Canada is grounded in the 'honour of the Crown', a concept that is corollary to s 35 of the Constitution Act, 1982. ${ }^{70}$ Reconciliation of Aboriginal peoples with the assertion of Crown sovereignty is its objective. Several Supreme Court decisions apply the honour of the crown principles, including: Calder et al $v$ Attorney-General of British Columbia $;{ }^{71}$ $R v$ Sparrow; $;^{72} R v$ Badger $;^{73}$ Mitchell $v$ Peguis Indian band ${ }^{74} R v$ Van der Peet $;{ }^{75} R v$ Nikal $;{ }^{76} R$ v Sundown; ${ }^{77}$ Delgamuukw $v$ British Columbia $;{ }^{78}$ Mitchell v MNR $;{ }^{79} R$ v Marshall ${ }^{80}$ Ross River Dena Council Band $v$ Canada; ${ }^{81}$ Wewaykum Indian Band $v$ Canada; ${ }^{82}$ Haida Nation $v$ British Columbia (Minister of Forests); ${ }^{83}$ Taku River Tlingit First Nation $v$ British Columbia (Project Assessment Director) $;{ }^{84} R$ v Marshall; $R$ v Bernard ${ }^{85}$ Mikisew Cree First Nation $v$ Canada (Minister of Canadian Heritage); 86 McDiarmid Lumber Ltd $v$ God's Lake First Nation; ${ }^{87} R v$ Kapp ${ }^{88}$ Quebec (Attorney General) v Moses; ${ }^{89}$ Rio Tinto Alcan Inc v Carrier Sekani Tribal Council $;^{90}$ Beckman $v$ Little Salmon/Carmacks First Nation, ${ }^{91}$ Bastien Estate v Canada $;{ }^{92}$ Lax Kw'alaams Indian Band v Canada (Attorney General); ${ }^{93}$ and, most recently, Manitoba Metis Federation Inc $v$ Canada (Attorney General). ${ }^{94}$ In its most recent consideration of the principle, the Court summarizes the state of the law as follows: 
[73] The honour of the Crown "is not a mere incantation, but rather a core precept that finds its application in concrete practices" and "gives rise to different duties in different circumstances:" Haida Nation, at paras 16 and 18. It is not a cause of action itself; rather, it speaks to how obligations that attract it must be fulfilled. Thus far, the honour of the Crown has been applied in at least four situations:

(1) The honour of the Crown gives rise to a fiduciary duty when the Crown assumes discretionary control over a specific Aboriginal interest (Wewaykum, at para 79 and 81; Haida Nation, at para 18);

(2) The honour of the Crown informs the purposive interpretation of $\mathrm{s} 35$ of the Constitution Act, 1982, and gives rise to a duty to consult when the Crown contemplates an action that will affect a claimed but as of yet unproven Aboriginal interest: Haida Nation, at para 25;

(3) The honour of the Crown governs treaty-making and implementation: Province of Ontario $v$ Dominion of Canada, (1895), 25 SCR 434, at p 512, per Gwynne J, dissenting; Mikisew Cree First Nation v Canada (Minister of Canadian Heritage), 2005 SCC 69, [2005] 3 SCR 388, at para 51 , leading to requirements such as honourable negotiation and the avoidance of the appearance of sharp dealing (Badger, at para 41); and

(4) The honour of the Crown requires the Crown to act in a way that accomplishes the intended purposes of treaty and statutory grants to Aboriginal peoples: $R$ $v$ Marshall, [1999] 3 SCR 456, at para 43, referring to The Case of The Churchwardens of St Saviour in Southwark (1613), 10 Co Rep 66b, 77 ER 1025, and Roger Earl of Rutland's Case (1608), 8 Co Rep 55a, 77 ER 555; Mikisew Cree First Nation, at para 51; Badger, at para $47 .{ }^{95}$

The Regulator may not have jurisdiction to consider the adequacy of Crown consultation, but it may nevertheless have obligations in law associated with Treaty implementation pursuant to the honour of the Crown principle. Such obligations are recognized in Ministerial Order $141 / 2013$.
Section 67 of the Responsible Energy Development Act allows the Minister to advise the Regulator. Pursuant to this authority Ministerial Order 141/2013 was signed by the Minister of Energy on November 26, 2013. This Direction is described as an 'Aboriginal Consultation Direction' - but it is more than this. The Ministerial Order recognizes that:

...[t]he AER has a responsibility to consider potential adverse impacts of energy applications on existing rights of Aboriginal peoples as recognized and affirmed under Part II of the Constitution Act, 1982, within its statutory authority under REDA; and

AER processes will constitute part of Alberta's overall consultation process as appropriate. $^{96}$

The recognition granted in this Order suggests that the Regulator may consider constitutional law issues, such as project impacts on existing rights of aboriginal peoples, as a matter of its routine functions. This does not support a narrow view of jurisdiction under the Administrative Procedures and Jurisdiction Act.

Alberta appears to intend to centralize its responsibility for assessing the adequacy of Aboriginal consultation by the Crown in an Aboriginal Consultation Office. The Ministerial Order was to have coordinated the work of the Regulator and this Office. An immediate concern, however, is that implementation may have a few hurdles to address. This is apparent on the face of the Ministerial Order itself. Ministerial Order 141/2013 also states that:

...This Direction applies to "applications" to the AER for "energy resource activity" "approvals" under "specified enactments", all as defined in REDA ("energy applications"). ${ }^{97}$

This awkward drafting could be read as limiting the application of the Ministerial Order to "specified enactments" only. But such a narrow reading would not seem to be consistent with the purpose of the Order, cited above ["...a responsibility to consider potential adverse impacts of energy applications on existing rights...."]. It appears to the author that reference to "speci- 
fied enactments" should not be used to limit the jurisdiction of the Regulator to consider adverse impacts on existing rights in respect of decisions under specified enactments, only. The Regulator should be obligated to consider project impacts on established rights, whether it is making a decision under the energy enactments or under the specified enactments.

The terms "applications" and "approvals" are defined in REDA and include applications and approvals under both the energy enactments and also the specified enactments. Section 1(1) (i) of REDA defines energy resource activity with regard to the energy resource enactments:

\section{1(1)(i) "energy resource activity" means}

(i) an activity that may only be carried out under an approval issued under an energy resource enactment, or

(ii) an activity described in the regulations that is directly linked or incidental to the carrying out of an activity referred to in subclause (i) ... [emphasis added].

The purpose of the Ministerial Order is to ensure that the Regulator's work considers project impacts on constitutionally protected rights. The modern approach to statutory interpretation $^{98}$ suggests that Ministerial Order 141/2013 cannot mean that the Regulator consider constitutionally protected Treaty rights only when exercising adjudicative functions under the specified enactments (and not when exercising adjudicative functions under the energy enactments).

\section{The Charter of Rights}

One particularly germane matter arises in relation to Charter rights and the actions of the Regulator. Since the Regulator is a public agency that exercises adjudicative functions in relation to approvals sought under the energy resource and other specified enactments, Doré v Barreau $d u$ Québec suggests that the Regulator must consider Charter values when these arise in relation to its functions:
[34] ... Today, the Court has two options for reviewing discretionary administrative decisions that implicate Charter values. The first is to adopt the Oakes framework, developed for reviewing laws for compliance with the Constitution. This undoubtedly protects Charter rights, but it does so at the risk of undermining a more robust conception of administrative law. In the words of Prof Evans, if administrative law is bypassed for the Charter, "a rich source of thought and experience about law and government will be overlooked" (p 73).

[35] The alternative is for the Court to embrace a richer conception of administrative law, under which discretion is exercised "in light of constitutional guarantees and the values they reflect" (Multani, at para 152, per LeBel J). Under this approach, it is unnecessary to retreat to a $\mathrm{s} 1$ Oakes analysis in order to protect Charter values. Rather, administrative decisions are always required to consider fundamental values. The Charter simply acts as "a reminder that some values are clearly fundamental and ... cannot be violated lightly" (Cartier, at $\mathrm{p}$ 86). The administrative law approach also recognizes the legitimacy that this Court has given to administrative decisionmaking in cases such as Dunsmuir and Conway. These cases emphasize that administrative bodies are empowered, and indeed required, to consider Charter values within their scope of expertise. Integrating Charter values into the administrative approach, and recognizing the expertise of these decision-makers, opens "an institutional dialogue about the appropriate use and control of discretion, rather than the older command-and-control relationship" (Liston, at p 100).

[55] How then does an administrative decisionmaker apply Charter values in the exercise of statutory discretion? He or she balances the Charter values with the statutory objectives. In effecting this balancing, the decision-maker should first consider the statutory objectives.

$\cdots$

[56] Then the decision-maker should ask how the Charter value at issue will best be protected in view of the statutory objectives. This is at the core of the proportionality exercise, and requires the decision-maker to balance the 
severity of the interference of the Charter protection with the statutory objectives. ${ }^{99}$

Assertions of Charter rights, particularly section 7 rights, can arise in relation to the work of the Regulator where issues of human health may be engaged ${ }^{100}$ As such, comments about the distinctions between constitutional issues, constitutional questions, and inquiries about differing models of interpretation of the APJA, are applicable mutatis mutandis.

It is difficult to see how the Regulator may apply Charter values if a notice of question of constitutional law under the APJA is required merely to confer upon it jurisdiction to consider those values. And, given the comments of the Minister in the Legislature when the Bill giving rise to the current APJA was introduced, ${ }^{101}$ it is difficult to characterize the intent of the Legislature as denying the Regulator the capacity to consider Charter values.

\section{Conclusions}

The observations discussed here suggest that litigation is foreseeable in relation to the capacity of the Regulator to consider constitutional law. Uncertainty about roles and responsibilities in respect of the Regulator's ability to consider project impacts on constitutionally protected rights, and about its role in Alberta's consultation process, is likely to attract the observation of the Court in Rio Tinto, at paragraph 62. ${ }^{102}$ Academic commentators suggest that the process of reconciliation is not being managed in a way which is consistent with the honour of the Crown. ${ }^{103}$

These questions would likely attract a correctness standard of review for the reasons articulated by the Supreme Court of Canada in Dunsmuir:

... true jurisdiction questions arise where the tribunal must explicitly determine whether its statutory grant of power gives it the authority to decide a particular matter. The tribunal must interpret the grant of authority correctly or its action will be found to be ultra vires or to constitute a wrongful decline of jurisdiction... ${ }^{104}$
Dunsmuir explains the Court's rationale: " $[t]$ he legislative branch of government cannot remove the judiciary's power to review actions and decisions of administrative bodies for compliance with the constitutional capacities of government." The Alberta Court of Appeal confirms that the correctness standard may also apply to constitutional issues. These "are necessarily subject to correctness review because of the unique role of $s 96$ courts as interpreters of the Constitution." ${ }^{105}$ Questions of the kind discussed here may also, in a given context, be seen as centrally important to the legal system as a whole because "such questions require uniform and consistent answers." These issues were reconfirmed by the Supreme Court in Smith v Alliance Pipeline Ltd ${ }^{106}$, and again in United Food and Commercial Workers, Local 401 v Alberta (Attorney General). ${ }^{107}$

Litigation in the contexts described should not be seen as necessarily negative. Courts "offer a venue for the peaceful resolution of disputes, and for the reasoned and dispassionate discussion of our most pressing social issues." 108

\section{Notes}

* The author practices law with the firm of Shores Jardine LLP in Edmonton. This article is developed from a paper delivered at the Constitutional Symposium organized at the University of Alberta in October of 2013 by the Centre for Constitutional Studies and the Legal Education Society of Alberta. It is prepared in accordance with the Code of Conduct of the Law Society of Alberta, which encourages lawyers to contribute to professional publications and education. It expresses the views of the author in his personal capacity, and any errors of fact, law or interpretation or style are solely those of the author. All sources cited are in the public domain. No use has been made of information sheltered by solicitor-client or other privilege.

1 Alberta Energy, Message from the Chair, online: Alberta Energy <http://www.energy.alberta. $\mathrm{ca} / \mathrm{Org} / \mathrm{pdfs} /$ FinalMessageChair.pdf $>_{i}$ Alberta Energy, Enhancing Assurance: Report and Recommendations of the Regulatory Enhancement 
Task Force to the Minister of Energy, online: Alberta Energy <http://www.energy.alberta.ca/Org/ pdfs/FinalEnhancingAssuranceReportREP.pdf $>$; Alberta Energy, Enhancing Assurance, Appendices , online: Alberta Energy <http://www.energy. alberta.ca/Initiatives/2792.asp >; Alberta Energy, Regulatory Enhancement Project; Stakeholder \& First Nations Engagement Summary, online: Alberta Energy <http://www.energy.alberta.ca/ $\mathrm{Org} / \mathrm{pdfs} /$ FirstNationsEngagementSummary. pdf $>$; and Alberta Energy, Regulatory Enhancement Project: Technical Report December 2010, online: Alberta Energy <http://www.energy.alberta.ca/ Org/pdfs/REPTechnicalReport.pdf $>$.

2 Michael G Massicotte, "Bill 2, Responsible Energy Development Act: the creation of a single energy regulator in Alberta" (2012) Borden Ladner Gervais LLP Oil and Gas Bulletin 3.

3 Designation of Constitutional Decision Makers Regulation, Alta Reg 69/2006, s 1.

4 Administrative Procedures and Jurisdiction Act, RSA 2000, c A-3, s 1 [APJA].

5 Rio Tinto Alcan Inc v Carrier Sekani Tribal Council, 2010 SCC 43, [2010] 2 SCR 650, at para 70. [Rio cited to SCR].

6 Responsible Energy Development Act, RSA 2012, R-17.3, s 21 [REDA]:"The Regulator has no jurisdiction with respect to assessing the adequacy of Crown consultation associated with the rights of aboriginal peoples as recognized and affirmed under Part II of the Constitution Act, 1982."

7 Beverley McLachlin, "Respecting Democratic Roles" (2005) 14: 3 Constitutional Forum 15 at 20.

8 Rio, supra note 5 at para 55, citing $R v$ Conway, 2010 SCC 22, [2010] 1 SCR 765.

$9 R v 974649$ Ontario, [2001] 3 SCR 575 at 578, 2001 SCC 81 [974649 cited to SCR], citing Bell Canada $v$ Canada (Canadian Radio-Television and Telecommunications Commission), [1989] 1 SCR 1722;, Re National Energy Board Act (Can), [1986] 3 FC 275 (CA), 29 DLR (4th) 35; and Interprovincial Pipe Line Ltd $v$ National Energy Board [1978] 1 FC 601.

10 Ibid at para 65, citing Newfoundland Telephone Cov Newfoundland (Board of Commissioners of Public Utilities), [1992] 1 SCR 623 at 634-35; and Canadian Pacific Ltd $v$ Matsqui Indian Band, [1995] 1 SCR 3 at para 117.

11 See Rio, supra note 5 at para 62: "The fact that administrative tribunals are confined to the powers conferred on them by the legislature, and must confine their analysis and orders to the ambit of the questions before them on a particular application, admittedly raises the concern that governments may effectively avoid their duty to consult by limiting a tribunal's statutory mandate. The fear is that if a tribunal is denied the power to consider consultation issues, or if the power to rule on consultation is split between tribunals so as to prevent anyone from effectively dealing with consultation arising from particular government actions, the government might effectively be able to avoid its duty to consult."

12 Dunsmuir v New Brunswick, [2008] 1 SCR 190 at para 31 [Dunsmuir cited to SCR].

13 Quebec (Attorney General) v Quebec (Human Rights Tribunal), [2004] 2 SCR 223, 2004 SCC 40, at para 28.

14 974649, supra note 9 at para 36.

15 Kent Roach, Constitutional Remedies in Canada (Aurora: Canada Law Book, 1994) at 14.40.

16 Paul v British Columbia (Forest Appeals Commission), [2003] 2 SCR 585, 2003 SCC 55, at para 36 [Paul cited to SCR].

$17 R v$ Conway, 2010 SCC 22, [2010] 1 SCR.

18 Rio, supra note 5 at para 69.

19 Cooper v Canada (Human Rights Commission), [1996] 3 SCR 854 at para 70; Nova Scotia (Workers' Compensation Board) v Laseur, [2003] 2 SCR 504, 2003 SCC 54, at para 29; Quebec (Attorney General) $v$ Quebec (Human Rights Tribunal), [2004] 2 SCR 223, 2004 SCC 40, at para 28; Okwuobi v Lester B Pearson School Board; Casimir v Quebec (Attorney General); Zorrilla $v$ Quebec (Attorney General), [2005] 1 SCR 257, 2005 SCC 16, at para 36; $R v$ Conway, 2010 SCC 22, [2010] 1 SCR 765, at para 77.

20 Alberta, Order in Council, 163/2013 (4 June 2013); Alberta, Order in Council, 357/2013 (6 November 2013); Alberta, Order in Council, 358/2013 (6 November 2013); Alberta, Order in Council, 359/2013 (6 November 2013); and Alberta, Order in Council, 36/2014 (26 February 2014).

21 Responsible Energy Development Act, SA 2012, c R-17.3 s 83(8).

83(8) The Lieutenant Governor in Council may make regulations

(a) respecting the transition to this Act of anything under the former Act or any other enactment, including

(i) transitional matters relating to applications, hearings, inquiries, investigations and other proceedings that have not been completed before the coming into force of this section, and

(ii) the interpretation of any transitional provision in this Act; 
(b) to remedy any confusion, difficulty, inconsistency or impossibility resulting from the transition to this Act from the former Act or any other enactment.

22 Responsible Energy Development Act Transition Regulation, Alta Reg 92/2013:

Completion of proceedings

2(1) Every proceeding commenced under the former Act, and every proceeding to which the former Act applied that was commenced under another enactment, that has not been completed before the coming into force of section 83(8) of the new Act shall be completed in accordance with the new Act.

(2) Without limiting the generality of subsection (1), every proceeding commenced or being conducted by the former Board

Hearing commissioners

3(1) Without limiting the generality of section 2, each member of the former Board who, before the coming into force of the new Act, is conducting a hearing, inquiry or other proceeding under the former Act that has not been completed on the coming into force of the new Act, is, on the coming into force of the new Act, deemed to be appointed as a hearing commissioner under section 11 of the new Act and to be a member of a panel under section 12 of the new Act for the purpose of completing the hearing, inquiry or other proceeding.

Rulings and decisions

4) For greater certainty, any decision or other action made or taken by the former Board in a proceeding that has not been completed before the coming into force of section 83(8) of the new Act continues as a decision or other action of the Regulator.

23 See Borden Ladner Gervais, The End of the ERCB - Responsible Energy Development Act Proclaimed in Force and Regulations Made, online: Oil and Gas Bulletin, June 2013 <http://www.blg.com/ en/newsandpublications/publication_3402>; Borden Ladner Gervais, Bill 2, Responsible Energy Development Act: The Creation of a Single Energy Regulator in Alberta, online: Oil and Gas Bulletin November 2012 <http://www.blg.com/ en/newsandpublications/publication_3402>; Borden Ladner Gervais, Streamlining the Regulatory Process: A Review of Alberta's Regulatory Enhancement Process, online" Oil and
Gas Bulletin July $2012<\mathrm{http} / /$ www.blg.com/en/ newsandpublications/publication_3402>; Osler LLP, Significant Changes to Alberta's Regulatory and Aboriginal Affairs Regime, online: Osler LLP Update (October 29, 2012) < http://www.osler. com/NewsResources/Significant-Changes-toAlbertas-Regulatory-and-Aboriginal-AffairsRegime/>. The University of Calgary's Faculty of Law posted numerous informative blogs at $<$ http:// ablawg.ca/>. Examples include: Arlene Kwasniak, The Responsible Energy Development Act and the Water Act - cloudy confluences, online: AbLawg $<$ http://ablawg.ca/2013/01/07/the-responsibleenergy-development-act-and-the-water-actcloudy-confluences/>; and Nigel Bankes, Bill 2 the Responsible Energy Development Act and the Duty to Consult, online: AbLawg <http://ablawg. ca/2012/11/19/bill-2-the-responsible-energydevelopment-act-and-the-duty-to-consult/>.

24 Alberta Energy Regulator Completes Transition to a Single Regulator, March 31, $2014<$ http://www.aer. $\mathrm{ca} /$ about-aer/media-centre/news-releases/newsrelease-2014-03-31>.

25 David LaidLaw and Monique Passelac-Ross, Alberta First Nations Consultation and Accommodation Handbook (Canadian Institute of Resources Law, University of Calgary) <http://cirl. $\mathrm{ca} /$ system/files/ConsultationHandbookOP44w. pdf $>$.

26 Ibid at $25-26$.

27 Ministerial Order 141/2013, original signed by the Minister of Energy on November 26, 2013. This Ministerial Order is discussed in Giorilyn Bruno and Nigel Bankes, The First Ministerial Direction to the Alberta Energy Regulator: The Aboriginal Consultation Direction, April 242014 at $<$ ABLAWG.ca $>$.

28 Nickie Vlavianos, An Overview of Bill 2: Responsible Energy Development Act - What are the changes and What are the issues? online: AbLawg: <http:// ablawg.ca/2012/11/15/an-overview-of-bill-2responsible-energy-development-act-whatare-the-changes-and-what-are-the-issues/>. See also: Nickie Vlavianos, The Legislative and Regulatory Framework for Oil Sands Development in Alberta: A Detailed Review and Analysis, online: Canadian Institute of Resources Law, $2007<\mathrm{http}: / /$ dspace.ucalgary.ca/bitstream/1880/47188/1/ OP21Oilsands.pdf $>$.

29 Lieutenant Governor in Council authority of this kind can be seen in the exercise of powers under ss 6,10 and 11 of the Oil Sands Conservation Act, RSA 2000, O-7; or section 7 of the Coal Conservation Act, RSA 2000, c-17. 
30 REDA, supra note 6 at s 67:

67(1) When the Minister considers it to be appropriate to do so, the Minister may by order give directions to the Regulator for the purposes of

(a) providing priorities and guidelines for the Regulator to follow in the carrying out of its powers, duties and functions, and

(b) ensuring the work of the Regulator is consistent with the programs, policies and work of the Government in respect of energy resource development, public land management, environmental management and water management.

(2) The Regulator shall, within the time period set out in the order, comply with directions given under this section

31 See for example the broad advisory power conferred upon the AER by section 17 of the REDA, supra note 6:

Inquiries and recommendations

17 The Regulator may, on its own initiative,... conduct inquiries and prepare studies and reports in respect of any matter relating to energy resources ... and ... recommend to the Lieutenant Governor in Council any measures it considers necessary or advisable related to a matter referred to ....

32 Alberta Public Agencies Governance Act, SA 2009, c A-31.5, s 1(1)(i).

33 Rio, supra note 5 at para 60.

34 See Gift Lake Metis Settlements v Metis Settlements Appeal Tribunal (Land Access Panel) 2009 ABCA 143: The Alberta Court of Appeal defines a helpful way of approaching the exercise of jurisdiction to consider cumulative effects:

[31] The following statement provides a helpful way of approaching cumulative effect:

Implicit in a cumulative effects assessment ... are effects from both the project as scoped and other projects or activities ... I am not sure it is possible to rule out that a federal project, while creating no adverse effects itself, could exacerbate adverse effects of other projects .... It is not illogical to think that the accumulation of a series of insignificant effects might at some point result in significant effects .... [A] finding of insignificant effects of the scoped projects is sufficient to open the possibility of cumulative significant environmental effects when other projects are taken into account.
Bow Valley Naturalists Society $v$ Canada (Minister of Canadian Heritage), [2001] 2 FC 461, 266 NR 169 at para 46.

[32] Similarly, "the destruction of any ecosystem or environment is a gradual process, effected by cumulative acts-a death by a thousand cuts ... "per Bourassa J in $R v$ Panarctic Oils Ltd (1983), 43 AR 199 at para 22 (NWT TC).

[33] While such statements are most applicable in their own statutory and factual contexts, they underscore the special nature of cumulative effect and its importance in situations where environmental degradation has occurred.

35 Nickie Vlavianos, "Alberta's Energy and Utilities Board and the Constitution of Canada," (2005) 43:2 Alberta Law Review 375 at 377.

36

\begin{tabular}{|l|l|}
$\begin{array}{c}\text { Concordance of Selected Statutory Provisions Material } \\
\text { to Jurisdiction to Consider Questions of Law }\end{array}$ \\
\hline Energy Resources Conservation Act & Responsible Energy Development Act \\
\hline Sections 16 and 20 & Section 14 \\
\hline Section 17(1)(a) & Section 13(1)(b) \\
\hline Section 21 & Section 17 \\
\hline Section 26(2) & Section 32 \\
\hline Section 36 & Section 55 \\
\hline Section 41(1) & Section 45(1) \\
\hline
\end{tabular}

37 Nova Scotia (Workers' Compensation Board) $v$ Martin, [2003] 2 SCR 504 at para 49 [Martin].

38 APJA, supra note 4.

39 Alberta Legislative Assembly, Official Report of Debates (Hansard), 26 ${ }^{\text {th }}$ Legislature, 1st Session, No 3 (21 March 2005) at 335.

40 Ibid.

41 Ibid at 356.

42 Designation of Constitutional Decision Makers Regulation, Alta Reg 66/2006.

43 APJA, supra note 4 at s 13(3): "Where the designated decision maker acts under subsection (1)(a) or (b), the designated decision maker must, unless otherwise directed by the court, suspend the proceeding, or any part of the proceeding, as it relates to the question to be heard by the court under subsection (1) until the decision of the court has been given."

44 Alberta Energy Regulator, Application for Bitumen Recovery Scheme: Athabasca Oil Sands Area, online: 2013 ABAER 014 <http://www.aer.ca/ documents/decisions/2013/2013-ABAER-014. pdf $>$.

45 Roach, supra note 15 at 14.50.

46 Paul, supra note 16 at para 23.

47 Ibid at paras 76-7.

4819802 SCR 451.

49 [1986] 1 SCR 285.

50 [1990] 1 SCR 901 [Horseman].

51 [1996] 1 SCR 771. 
52 [1996] 2 SCR 723.

53 [2003] 2 SCR 236.

54 Peter W Hogg, Constitutional Law of Canada, vol 2, 5th ed (Scarborough: Thomson, 2007) at 28.11.

55 Ibid at 28.19.

56 Ibid at 28.12

57 Ibid at 28.15 .

58 Government of Canada, Recovery Strategy for the Woodland Caribou, Boreal population (Rangifer tarandus caribou) in Canada, online: Species at Risk Public Registry <http://www.sararegistry.gc.ca/ document/default_e.cfm?documentID=2253>.

59 Horseman, supra note 50 at 929.

60 Slaight Communications Inc v Davidson, [1989] 1 SCR 1038 at 1078.

61 Paul, supra note 16 at para 16.

62 Ibid at para 21.

63 Ibid at para 25.

64 Ibid at para 39.

65 Martin, supra note 37 at para 28.

66 Government of Albert, Alberta's Policy on Consultation with First Nations on Land and Natural Resource Management, 2013, online: Aboriginal Relations <http://www.aboriginal. alberta.ca/1.cfm>.

67 See Energy Resources Conservation Board, Application to Construct and Operate an Oil Sands Upgrader in Sturgeon County, online: ERCB <http://www.aer.ca/documents/ decisions/2009/2009-002.pdf> and <http://www. aer.ca/documents/decisions/2009/2009-002. pdf>; and Energy Resources Conservation Board, Report of the Joint Review Panel, Joslyn North Mine Project, online: ERCB <http://www.ceaa-acee. gc.ca/050/documents/48613/48613E.pdf >.

Similar notices are discussed in: KirkLambrecht, "Assessing and Managing the Cumulative Effects of Oil Sands Development in Alberta;" in Stanley Berger, ed, Key Developments in Environmental Law 2011 Edition (Toronto: Canada Law Book, 2011); See also Neil Reddekopp, "Theory and Practice in the Government of Alberta's Consultation Policy" (2013) 22:1 Constitutional Forum_at 47-62.

In addition to these, a number of letter decisions of the ERCB were issued and are the subject of an AbLawg comment: Nigel Bankes, The letter decisions of the Energy Resources Conservation Board (6 September 2012), online: AbLawg <http://ablawg.ca/wp-content/uploads/2012/09/ Blog_NB_Letter_Decision_ERCB_Sept 20121 . pdf $>$ (These include the ERCB Reasons for July 17, 2012 Decision on Notice of Question of Constitutional Law, Osum Oil Sands Corp., Taiga Project, issued on August 24, 2012).

Conservation Board), 2012 ABCA 304; and Métis Nation of Alberta Region 1 voint Review Panel, 2012 ABCA 352.

Private sector and academic commentary can be found at:

Lawson Lundell, Alberta Court of Appeal Leaves Question of ERCB's Jurisdiction to Assess Crown Consultation to Another Day (23 October 2012), online: Project Law Blog <http://www. projectlawblog.com/2012/10/23/alberta-courtof-appeal-leaves-question-of-ercbs-jurisdictionto-assess-crown-consultation-to-anotherday/\#page=1>; Lawson Lindell, Joint Review Panel Finds It Lacks the Necessary Jurisdiction to Adjudicate Crown Consultation with First Nations (9 November 2012), online: Project Law Blog <http://www.projectlawblog.com/2012/11/09/ joint-review-panel-finds-it-lacks-the-necessaryjurisdiction-to-adjudicate-crown-consultationwith-first-nations/>; Fasken Martineau, Court of Appeal Declines (Again) to Decide Who Has to Assess the Adequacy of Consultation (29 November 2012), online: Aboriginal Law Bulletin <http://www. fasken.com/en/court-of-appeal-declines-againto-decide-who-has-to-assess-the-adequacy-ofconsultation/>; Fasken Martineau, Who Judges Adequacy? A New Arena Emerges in the Duty to Consult (31 October 2012), online: Aboriginal Law Bulletin <http://www.fasken.com/en/whojudges-adequacy-a-new-arena-emerges-in-theduty-to-consult/>; and University of Calgary, Duty to consult application is premature - what's the big deal? (4 December 2012), online: AbLawg <http://ablawg.ca/wp-content/uploads/2012/12/ Blog_NB_Jackpine_Mine_Dec2012.pdf $>$.

69 Supreme Court of Canada, Athabasca Chipewyan First Nation $v$ Energy Resources Conservation Board acting in its capacity as part of the Joint Review Panel, Joint Review Panel, et al (Docket Summary 35193), online: Supreme Court of Canada <http:// www.scc-csc.gc.ca/case-dossier/info/dock-regieng.aspx? cas $=35193>$.

70
Rio, supra note 5 at para 32 .

[1973] SCR 313, [1973] 4 WWR 1.

[1990] 1 SCR 1075, 1990 CarswellBC 105 (SCC).

[1996] 1 SCR 771, 2 CNLR 77 (SCC).

[1990] 2 SCR 85.

[1996] 2 SCR 507, 1996 CarswellBC 2310 (SCC).

[1996] 1 SCR 1013.

[1999] 1 SCR 393.

[1997] 3 SCR 1010, 1997 CarswellBC 2358 (SCC). [2001] 1 SCR 911, 2001 CarswellNat 874 (SCC). [1999] 3 SCR 456, 1999 CarswellNS 262 (SCC). 
81 [2002] 2 SCR 816, 2002 SCC 54.

82 [2002] 4 SCR 245, 2002 SCC 79.

83 [2004] 3 SCR 511, 2004 SCC 73.

84 [2004] 3 SCR 550, 2004 SCC 74.

85 [2005] 2 SCR 220, 2005 SCC 43.

86 [2005] 3 SCR 388, 2005 SCC 69.

87 [2006] 2 SCR 846, 2006 SCC 58.

88 [2008] 2 SCR 483, 2008 SCC 41.

89 [2010] 1 SCR 557.

90 Rio, supra note 5.

91 [2010] 3 SCR 103.

922011 SCC 38.

932011 SCC 56, [2011] 3 SCR 535.

942013 SCC 14.

95 Ibid.

96 Alberta Energy Regulator, Public Notice of Application $Q$ \& $A$, online: Alberta Energy Regulator $<$ http://www.aer.ca/about-aer/what-wedo/Q-and-A-PNoA $>$.

97 Ibid.

98 "Today there is only one principle or approach, namely, the words of an Act are to be read in their entire context and in their grammatical and ordinary sense harmoniously with the scheme of the Act, the object of the Act, and the intention of Parliament." See E. A. Driedger, Construction of Statutes (2nd ed. 1983), at p. 87.

992012 SCC 12, [2012] 1 SCR 395 [Doré cited to SCR].

1002014 ABAER 005, Report of Recommendations on Odours and Emissions in the Peace River Area, March 31, 2014, at <http://www.aer.ca/documents/ decisions/2014/2014-ABAER-005.pdf $>$.

101 Ibid at 396.

102 "The fact that administrative tribunals are confined to the powers conferred on them by the legislature, and must confine their analysis and orders to the ambit of the questions before them on a particular application, admittedly raises the concern that governments may effectively avoid their duty to consult by limiting a tribunal's statutory mandate. The fear is that if a tribunal is denied the power to consider consultation issues, or if the power to rule on consultation is split between tribunals so as to prevent anyone from effectively dealing with consultation arising from particular government actions, the government might effectively be able to avoid its duty to consult."

103 David LaidLaw and Monique PasselacRoss, Alberta First Nations Consultation and Accommodation Handbook (Canadian Institute of Resources Law, University of Calgary), at page 60.

104 Dunsmuir, supra note 12 at para 59.
105 Shaw $v$ Alberta (Utilities Commission), 2012 ABCA 378, 539 AR 315.

1062011 SCC 7 [2011] 1 SCR 160 at para 26.

1072012 ABCA 130 at paras 37-44.

108 Supreme Court of Canada, Words of Welcome from the Chief Justice of Canada, online: Supreme Court of Canada <http://www.scc-csc.gc.ca/homeaccueil/index-eng.aspx $>$. 
